\title{
KAJIAN SEMIOTIKA BARTHES CERPEN PUTIK SAFRON DI SAYAP IZRAIL KARYA AKMAL NASERY BASRAL
}

\author{
Natalia Endah Hapsari \\ E-mail: dosen02553@unpam.ac.id \\ Universitas Pamulang, Tangerang Selatan
}

\begin{abstract}
Abstrak
Pandemi Covid 19 berpengaruh pada karya-karya sastra yang dihasilkan oleh para penulis atau sastrawan di Indonesia. Penelitian ini berfokus untuk meneliti karya sastra dalam bentuk cerita pendek atau cerpen Putik Safron di Sayap Izrail karya Akmal Nasery Basral yang terbit di Harian Republika pada tanggal 17 Mei 2020. Cerpen ini dianalisis dengan menggunakan metode semiotika Roland Barthes. Dalam prosedur pengumpulan data langkah-langkah yang dilakukan adalah melakukan pembacaan terhadap cerpen serta studi pustaka. Setelah itu peneliti akan memecah teks ke dalam beberapa leksia yang selanjutnya leksia-leksia akan dikelompokkan dalam lima macam kode pembacaan yaitu kode hermeneutik, kode semik, kode simbolik, kode proaeretik, dan kode kultural atau referensi.Dari hasil penelitian diketahui cerpen ini memiliki 67 leksia dan diperoleh kesimpulan bahwa cerpen ini mengangkat isu kesehatan yang saat ini melanda seluruh dunia serta hadir pula penggambaran tentang kedaruratan penyakit tersebut yang menimbulkan kecemasan sosial yang berujung pada kematian.
\end{abstract}

Kata kunci: cerpen, cerita, leksia, pandemi, semiotika

\section{Pendahuluan}

Awal tahun 2020, dunia mengalami guncangan akibat pandemi Covid 19 yang merebak. Organisasi Kesehatan Dunia (WHO) menyatakan bahwa Corona Virus Disease 2019 (Covid-19) sebagai pandemi global pada Rabu, 11 Maret 2020. Pernyataan tersebut berdasarkan pada penyebaran sekitar 118 ribu kasus yang melanda di 114 negara. Kasus pertama Covid-19 sendiri kali pertama terdeteksi di Kota Wuhan, Cina, pada akhir Desember 2019, dan kemudian menjadi wabah berselang satu bulan kemudian atau tepatnya pada awal Januari. Sejak itulah penyakit ini pun terus menyebar dan tak terkecuali melanda juga hingga ke Tanah Air. Presiden RI Joko Widodo mengumumkan kasus pertama 
positif Covid-19 di Indonesia pada Senin, 2 Maret 2010, yang ditularkan melalui transmisi dari manusia ke manusia (KPCPEN, 2020).

Lantaran mengguncang nyaris seluruh sendi kehidupan umat manusia di dunia, pandemi ini pun berpengaruh terhadap karya sastra yang dihasilkan. Ini terlihat dari berbagai karya sastra yang berlatar virus korona atau Covid 19. Karya sastra seperti puisi hingga cerpen mengusung latar virus korona tersebut. Di sejumlah surat kabar pun bermunculan cerpen yang berlatar korona. Hal ini menarik untuk ditelaah lebih lanjut terutama untuk mengulas dari pendekatan teori semiotika terhadap karya sastra terutama cerpen. Pemilihan cerpen dalam penelitian ini dikaitkan dengan observasi peneliti bahwa saat ini sebagian besar media massa masih rutin memuat cerpen sebagai bentuk apresiasi terhadap karya sastra di tanah air. Ini berlaku untuk media massa cetak dan daring.

Namun untuk meneliti karya sastra seperti cerita pendek (cerpen) tentu memerlukan landasan teori agar dapat mengungkap makna dari sebuah karya sastra. Sebuah teori yang dapat dipakai dalam memunculkan makna dari sebuah karya sastra itu adalah teori semiotika. Dalam penelitian, teori semiotika yang digunakan adalah teori yang dibuat oleh Roland Barthes. Dalam penelitian sastra tentu diharapkan ada manfaat yang dapat diambil penulis cerpent tersebut sebagai sastrawan dan peneliti yang juga berpredikat sebagai penikmat karya sastra yang diteliti (Widyatwati, 2015).

Untuk penelitian ini, penulis akan meneliti cerpen berjudul Putik Safron di Sayap Izrail karya Akmal Nasery Basral yang terbit di Harian Republika pada tanggal 17 Mei 2020. Pemilihan cerpen ini atas dasar cerpen inilah yang menjadi judul yang dipilih dalam buku antologi cerpen karya Akmal Nasery Basral (ANB).

\section{Metode Penelitian}

Ada pun skema penelitian ini adalah dalam mengumpulkan data, langkah yang diambil oleh peneliti adalah membaca cerpen tersebut, melakukan studi pustaka serta memecah teks cerpen dalam beberapa leksia sesuai ketentuan semiotika Barthes. Setelah itu leksia tersebut akan dianalisis dengan 
menggunakan lima kode Barthes. Hal tersebut dilakukan agar dapat mengungkap struktur dan pemaknaan yang terdapat dalam dua cerpen yang diteliti tersebut. Dari objek penelitian tersebut, maka masalah penelitian ini adalah bagaimana struktur dan makna cerpen 'Putik Safron di Sayap Izrail' dilihat dari teori semiotika. Maka, berdasarkan masalah penelitian tersebut, maka tujuan penelitian ini adalah untuk mengetahui bagaimana pandemi ini berpengaruh terhadap karya sastra yang muncul terutama dalam hal ini adalah cerita pendek (cerpen).

\section{Hasil Penelitian dan Pembahasan}

\section{(1) Putik Safron di (2) Sayap Izrail}

Judul dalam cerpen ini mengandung dua leksia. *Leksia pertama yaitu 'Putik Safron' merupakan bagian dari judul cerita. Dalam kisah ini, sang penulis menjelaskan arti safron yaitu berupa nama rempah-rempah dengan nama Latin Crocus sativus yang memiliki kepala putik (stigma) seperti benang. Di awal kisah, leksia ini menimbulkan pertanyaan atau teka-teki tentang keterkaitan keberadaan putik safron dengan alur cerita. **Leksia kedua yaitu 'Sayap Izrail' masuk dalam pentemaan untuk kategori kode hermeneutika karena terkait dengan alur cerita yang memaparkan tentang kematian. Izrail yang merupakan nama malaikat maut dalam agama Islam. Leksia ini pun serupa dengan leksia 65 yang lebih mendeskripsikan lebih detail tentang sosok Izrail tersebut. *** Dalam ajaran agama, Izrail adalah malaikat pencabut nyawa. Leksia ini pun mengungkap sebagian jawaban tentang teka-teki yang hadir dalam teks yang menyiratkan adanya gambaran kematian yang akan dialami oleh sang tokoh. **** Leksia tersebut juga menyimbolkan eksistensi malaikat dengan simbol sayap padanya.

(3) Mang Embot tak mempercayai penglihatannya. Diedarkannya pandangan ke sekeliling. Leksia ini masuk dalam kode hermeneutika untuk kategori pengacauan. Leksia ini menimbulkan pengacauan karena pembaca boleh jadi bertanya-tanya tentang lingkungan baru yang dialami oleh si tokoh tersebut.

(4) “Subhanallah!” desisnya berulang kali dengan takjub. Leksia ini menggambarkan keimanan sang tokoh yang mengungkap rasa kagumnya lewat 
kalimat tasbih. Leksia ini juga terkait dengan leksia 16 yang menegaskan keimanan tokoh Mang Embot sehingga masuk dalam kode kultural.

(5) Ini memang jalan yang biasa ditempuh ke kota yang berjarak $15 \mathrm{~km}$ dari kampungnya di pinggang Bukit Halimun. Jalan tanah berbatu, semak belukar di beberapa bagian, dan rompal di bagian lain karena terban. Tak jarang tercium bau busuk bangkai hewan bercampur tumpukan sampah. Leksia ini masuk dalam kategori pengacauan kode hermeneutika lantaran dijelaskan lebih lanjut kondisi aneh tersebut lantaran jalan yang biasa ditempuhnya tersebut rupanya menghadirkan suasana berbeda yang telah dideskripsikan dalam situasi asri, gemericik air, dan wangi. Leksia ini pun terkait dengan leksia 6.

(6) Tetapi kali ini semua yang dilihatnya berbeda. Lingkungan asri menyenangkan mata, gemercik air merdu di telinga. Udara wangi membuat nyaman rongga dada. Selain masuk dalam kategori pengacauan, leksia ini juga menimbulkan teka-teki kategori penundaan jawaban.

(7) Yang paling istimewa terlihat sebuah masjid dengan kubah mutiara. Dindingnya pualam kelas satu. Begitu permata. Leksia ini mengandung penundaan jawaban yang menghadirkan petunjuk lewat gambaran bangunan masjid dengan kubah mutiara. Adanya kehadiran masjid yang indah menjadi jawaban sebagian dari teka-teki keberadaan sang tokoh.

(8) Dengan degup hati menggila didekatinya masjid itu. Jantungnya nyaris meledak mencium keharuman menguar dari teras. Enak sekali. Jika terasnya saja seperti ini, bagaimana kondisi di dalamnya? Leksia ini masuk dalam kode proaeretik atau aksi naratif yang terkait dengan aksi ibadah sang tokoh utama.

(9) Mang Embot tak paham bagaimana dalam sekedipan mata dia sudah di tempat wudhu. Air mengalir begitu saja mengucur tepat di depannya, tanpa keran. Begitu jernih dengan suhu nyaman. Bagi umat Muslim, masjid adalah rumah Allah di dunia. Gambaran rumah Allah senantiasa damai, indah, dan menyejukkan. Leksia ini yang sebangun pula dengan leksia 8, 14, serta 15 memberikan gambaran suasana serta keindahan dan kemewahan rumah Allah atau masjid yang ditemui oleh tokoh Mang Embot. 
(10) Usai bersuci, Mang Embot ragu memasuki masjid karena pakaiannya tambal sulam. Bagaimana dia memasuki Rumah Allah? Sedangkan memasuki pendopo desa ketika lurah hadir saja harus rapi. Apatah lagi kini sebagai makhluk yang memasuki Rumah Khalik. Leksia ini masuk dalam kategori tekateki atau kode hermeneutika yaitu pengusulan masalah lantaran leksia tersebut menimbulkan masalah ketika sang tokoh tiba-tiba memasuki masjid yang disebutnya sebagai Rumah Khalik. **Leksia ini juga masuk dalam kategori aksi dalam kode proaeretik yang dikaitkan dengan kebiasaan beribadah tokoh utama.

(11) Namun kakinya terus bergerak seakan didorong kekuatan gaib dari belakang. "Hei!" Mang Embot memprotes. Dia menoleh ke belakang, tak ada orang. Leksia ini bisa menimbulkan kekacauan yang tergolong kode hermeneutika karena kenyataan yang dihadapi sang tokoh justru berbeda.

(12) Kedua kakinya menginjak teras masjid. Telapak kakinya yang tebal, kasar, dan pecah-pecah, kini terawat seperti kaki bangsawan. Begitu pun tangannya. Jemarinya yang kapalan kini bak tangan pangeran. Lebih ajaib lagi, pakaian usangnya menjadi gamis panjang beludru kelas satu. Leksia ini yang dikaitkan pula dengan leksia 11,13, dan 17 menyimbolkan kehidupan di dunia yang lain yang jauh berbeda dengan kehidupan di dunia seperti adanya simbol keindahan, wajah menawan, suara merdu serta makhluk tak kasat mata.

(13) Sebelum memasuki ruang utama, dia melihat pantulan wajahnya pada kaca. Astaga, wajah keriputnya tiada! Yang terlihat paras diri saat berusia 30-an. Aneh. Leksia ini masuk kategori hermeneutika yaitu teka-teki serta menimbulkan kekacauan lantaran Mang Embot justru tampak muda.

(14) Mang Embot tak sempat memikirkan lagi karena kakinya terus mengancik ruang ibadah utama yang membuatnya semakin kagum. Leksia ini dikategorikan dalam kode aksi naratif lantaran menunjukkan kesungguhan tokoh utama untuk bersiap memasuki ruang masjid untuk memulai shalat.

(15) Sebuah keindahan yang tak tergambarkan. Leksia ini masuk kategori pengacauan kode hermeneutika lantaran peristiwa yang dialami tokoh utama tak ayal menimbulkan kebingungan sehingga tidak mampu lagi mendeskripsikan situasi yang dihadapinya. Kekacauan lantas timbul karena situasi tersebut tidak 
dapat digambarkan dengan gamblang lantaran tak dapat ditafsirkan secara akal sehat.

(16) Ditunaikannya shalat Tahiyyatul Masjid. Leksia ini masuk dalam kategori kode aksi yang dikaitkan dengan kebiasaan atau aksi ibadah sang tokoh yang dijelaskan lewat tindakannya menunaikan shalat tahiyyatul masjid.

(17) Lidahnya nyaman mendaraskan rangkaian kalimat ilahi yang cukup terdengar oleh telinganya sendiri. Suara secempreng piring kaleng yang biasa keluar dari mulutnya berubah semerdu suara qari pemenang MTQ. Leksia ini pun masuk dalam kode simbolik karena menyiratkan tentang kehidupan yang berbeda dari dunia yang selama ini dilakoni sang tokoh.

(18) Air matanya mengalir. Kelopak matanya terpejam, karam dalam samudera kebahagiaan. *Leksia ini masuk dalam kode hermeneutika kategori penundaan jawaban karena situasi mengejutkan yang dialami oleh tokoh utama itu ** Air mata tak jarang diidentikkan dengan kesedihan dan duka. Namun, ada kalanya air mata merupakan simbol dari kebahagiaan tiada tara. Leksia ini menyimbolkan rasa bahagia lewat air mata yang mengalir.

(19) Saat matanya terbuka, Mang Embot tertegun. Leksia masuk dalam kode hermeneutika yaitu teka-teki kategori pengacauan lantaran sang tokoh utama tertegun terhadap keadaan yang dialaminya.

(20) Matanya terhalang gumpalan kapas. Ketika ajal menjemput, jenazah pun diperlakukan dengan kondisi khusus seperti posisi tubuh yang membujur dan terbungkus kain kafan. Leksia ini, yang terkait pula dengan leksia 21, 22, dan 23, menggambarkan dengan detail posisi sang tokoh yang serupa dengan posisi saat jenazah disemayamkan.

(21) Posisi tangannya bersidekap erat di dada, tak bisa digerakkan. (22) Tubuhnya terbungkus kain ketat. (23) Badannya membujur dengan posisi kaki dan kepala sejajar, tidak seperti saat shalat. *Dalam leksia tersebut, teka-teki muncul karena sang tokoh merasa kesulitan lantaran matanya yang terhalang kapas. Leksia 20,21,22,23 memiliki benang merah lantaran sang tokoh mengalami situasi yang berbeda dari kesehariannya.**Leksia ini juga masuk dalam kategori pengacauan lantaran sang tokoh mengalami situasi yang tidak biasa. 
(24) Apakah ini mimpi? Atau kenyataan sejati? Teka-teka tersebut kian kuat dalam leksia ini lantaran sang tokoh pun turut menanyakan kondisinya yang tak biasa itu apakah mimpi atau realita.

(25) Tak ada warga Bukit Halimun yang tahu nama asli Mang Embot. Dia selalu merendah dengan menyebut profesi sebagai merbot masjid. "Panggil Embot saja," katanya seperti diingat para tetua. Dalam leksia 25 dan 26 pembaca diajak untuk mengetahui tempat asal Mang Embot lewat sapaan yang diberikan masyarakat padanya.

(26) Namun warga merasa risih jika memanggil nama saja. Mereka menambahkan panggilan “Mang” untuk menghormati. Sapaan 'mang' biasanya diberikan pada orang yang lebih tua atau dihormati di lingkungannya. Leksia 25 dan 26 menyimbolkan sapaan untuk orang yang lebih tua atau dihormati.

(27) Di tangan Mang Embot, masjid mereka yang sederhana tak pernah kotor apalagi menyebar bau tak sedap. Area buang hajat pun tak pesing. Mang Embot selalu membersihkan dengan teliti lantai tempat ibadah yang dilapisi karpet hijau pudar, menjaga sudut-sudut plafon dari sarang laba-laba, menyikat ubin tempat wudhu sehingga tak ada lumut yang bisa membuat jamaah terpeleset. Sang tokoh digambarkan sangat berdedikasi saat menjalankan profesinya sebagai merbot sehingga tepat masuk dalam leksia aksi. Leksia ini pun terkait dengan leksia 31 yang juga mengungkap dedikasi Mang Embot terhadap masjid meski dia juga punya profesi lain yaitu sebagai pemijat.

(28) Tubuh Mang Embot kurus, liat, dengan urat menonjol di sekujur tangan dan kaki. Tubuhnya didera penyakit gula dan nyeri berulang di bagian perut, yang setelah diperiksa dokter hasilnya positif kanker usus. Lewat leksia ini, pembaca dibuat mulai memahami kondisi yang dialami sang tokoh yaitu kondisi tubuhnya yang makin kurus sehingga memberikan sebagian jawaban tentang kondisi kesehatan tokoh ini dan masuk dalam kode hermeneutika .

(29) Mang Embot menyimpan rahasia ini dari pengetahuan jamaah meski istrinya menyarankan agar berterus terang. Leksia ini memicu masalah sehingga masuk dalam kode hermeneutika karena sang tokoh utama memilih untuk 
menyimpan rahasia penyakit tersebut meski sang istri memintanya berterus terang.

(30) "Sakitku tak ada seujung kuku penderitaan Nabi Ayub. Lagi pula sebagian besar hidupku selalu sehat. Penyakit bermunculan karena tambah tua saja. Itu biasa. Kamu, Ambu, jangan pernah keceplosan mengatakan soal ini kepada siapa pun," katanya tegas. Nabi Ayub adalah nabi yang dikenal dengan kisah kesabarannya yang luar biasa meski diuji oleh berbagai penyakit selama 18 tahun. Meneladani Nabi Ayub, leksia ini menyimbolkan kesabaran Mang Embot ketika didera penyakit.

(31) Mang Embot juga pandai memijat dan bersedia dipanggil kapan saja dengan satu kondisi: 30 menit sebelum waktu shalat wajib tiba, dia harus berada di masjid. Leksia ini sebangun dengan leksia 27 yaitu berkode aksi karena menceritakan dedikasi sang tokoh yang setia melakoni profesinya sebagai merbot.

(32) Salah seorang jamaah penggemar pijatan Mang Embot adalah Haji Dulgani, pedagang antarprovinsi. (33) Usai dipijat, Haji Dulgani selalu memberikan uang dalam amplop dan hadiah. Dari baju koko model terbaru (lengkap dengan baju muslimah bagi istri Mang Embot), kopiah motif unik, sarung bordir indah, mushaf Alquran cetakan terbaru. Dalam masyarakat, keberadaan amplop sering kali diidentikan dengan uang. Tanpa menjelaskan secara gamblang, kehadiran 'amplop' dalam leksia 33 yang kemudian disebutkan lebih detail sebagai 'amplop tebal' pada leksia 48 memberikan simbol adanya pemberian uang dalam jumlah besar kepada tokoh Mang Embot atas jasanya memijat.

(34) Satu saat Haji Dulgani memberikan hadiah berbeda berupa gumpalan benang merah seukuran sendok makan. *Gumpalan benang merah menimbulkan kekacauan sehingga masuk dalam kode hermeneutika lantaran bisa jadi belum banyak yang paham dan familiar dengan bentuk safron meski pada leksia 36 telah dipaparkan lebih lanjut deskripsi safron tersebut. ** Simbol berupa gulali, benang putik bunga hingga gumpalan benang merah yang hadir pada leksia 34 dan 36 tampaknya bisa menjadi gambaran yang cukup deskriptif agar pembaca juga dapat mengasosiasikan ini sebagai rempah berkhasiat bernama safron. 
(36) “Kenapa Ajengan memberikan saya gulali?” Mang Embot bingung. “Ini bukan gulali," Haji Dulgani tersenyum. "Ini safron, rempah istimewa." “Kelihatannya seperti benang putik bunga?” Dalam leksia ini disebutkan adanya safron atau rempah khusus. Leksia ini pun hanya mengungkap jawaban sebagian dari teka-teki safron yang disebutkan sebagai rempah istimewa sehingga masuk dalam kode hermeneutika kategori teka-teki dengan jawaban sebagian.

(37) “Betul, tapi bukan sembarang bunga. Untuk dapat satu sendok makan seperti ini dibutuhkan lebih dari 150 bunga. Tumbuhnya sebagian besar di Iran, India, dan beberapa negara lain. Kebetulan saya baru dari India."

*Leksia ini masuk dalam kode hermeneutika kategori teka-teki dengan jawaban sepenuhnya. Jawaban sepenuhnya merupakan istilah yang digunakan untuk menyebutkan kode yang memberikan jawaban secara menyeluruh. Jawaban dalam kategori ini adalah jawaban yang kompleks. ** Leksia 36, 37, 40 dan 41 pun membawa pembaca untuk mengenal rempah safron yang disebutkan berasal dari India. Leksia ini pun masuk dalam kode teka-teki dengan kategori jawaban sepenuhnya karena pembaca dapat memahami manfaat dari safron tersebut.

(38) Mang Embot terbelalak. "Subhanallah. Kenapa diberikan buat saya, Ajengan? Saya tidak tahu cara menanamnya." "Memang bukan untuk ditanam, tapi buat obat.” “Obat?” Mang Embot semakin terbeliak. “Mang Embot memang tak pernah bilang punya penyakit. Tetapi saya lihat Mang Embot juga tak selalu sehat ..." Leksia ini masih terkait dengan leksia 37 di mana pembaca mendapatkan jawaban sepenuhnya tentang komposisi dan khasiat safron yang sebenarnya.

(39) "Saya sehat, alhamdulillah," potong Mang Embot yang cemas rahasianya terungkap. *Leksia ini termasuk dalam kode hermeneutika kategori pengacauan. ** Leksia 38 dan 39 menggambarkan kondisi kesehatan tokoh Mang Embot yang disangsikan sehingga masuk kode teka-teki kategori pengacauan.

(40) “Syukurlah kalau begitu," tukas Haji Dulgani. "Safron bisa menjadi obat kanker, diabetes, dan banyak penyakit lain. Rendam sehelai benang safron dalam air putih, tunggu sampai warna air berubah kuning, lalu diminum satu gelas sehari. Untuk jaga kesehatan." 
(41) Begitulah awalnya. Setiap hari Mang Embot minum segelas air safron. Setelah sebulan, dia rasakan kondisi tubuhnya membaik. Siksaan penyakit gula dan kanker ususnya jauh berkurang. Kini persediaan safronnya habis, dan belum ada panggilan memijat lagi dari pedagang itu.Safron menjadi obat atau rempah yang menjadi objek utama dalam cerita ini. Leksia 40 menjelaskan aksi pengobatan yang dijelaskan oleh tokoh Haji Dulgani pada Mang Embot. Ini terkait pula dengan leksia 41, 48, dan 51 yang menjelaskan keampuhan safron yang dialami Mang Embot.

(42) Baru dua bulan kemudian Haji Dulgani yang baru kembali dari Cina meminta Mang Embot untuk memijat lagi. Dalam leksia ini, nama negara tersebut memicu teka-teki karena dinilai sebagai tempat yang paling terkait dengan penyebaran penyakit. Leksia ini pun menimbulkan pertanyaan karena dalam teks tidak dipaparkan lebih jauh keterkaitan antara negara ini dan penyakit yang diderita. Leksia ini juga terkait dengan leksia 37 yang menyatakan bahwa sang tokoh Haji Dulgani pun sempat berkunjung ke India.

(43) Istri Haji Dulgani menyambutnya di depan pintu dengan cemas. “Mang Embot, selesai pijat Abah tolong suruh dia ke dokter." "Memang Ajengan sakit apa?" Mang Embot penasaran. “Dia bilang kecapekan biasa,” ujar perempuan itu. "Tolong ya Mang. Kalau saya yang bilang Abah nggak mau dengar." Leksia ini pun memicu teka-teki sehingga masuk dalam kode hermeneutika karena penyakit Haji Dulgani belum dapat terdeteksi. Leksia ini juga masih masuk dalam kategori kekacauan kode hermeneutika karena penyakit tokoh Haji Dulgani yang belum diketahui penyebabnya.

(44) Istri Haji Dulgani mengantarkan Mang Embot menuju kamar tidur utama yang membuat Mang Embot ragu. "Kenapa di sini? Biasanya di ruang keluarga yang ada teve karena Ajengan suka dipijat sambil nonton berita.” “Abah sendiri yang minta dipijat di kamar kali ini.” Selain sebagai merbot, Mang Embot memang dikenal piawai juga memijat sehingga masuk dalam kategori kode aksi. Leksia ini terkait pula dengan leksia 43 dan 45.

(45) Dengan sungkan Mang Embot memasuki kamar itu. Haji Dulgani menyapanya sebentar, sebelum tertidur mendengkur begitu kelihaian tangan 
Mang Embot menyentuh tubuhnya. Biasanya dia tak pernah tertidur selama dipijat, selalu bercerita banyak hal yang dialaminya pada kota yang baru dikunjungi. Isu kesehatan juga dialami oleh tokoh Haji Dulgani dalam leksia 45, 57, dan 58. Untuk leksia ini, Haji Dulgani digambarkan sebagai tokoh yang memiliki kesibukan yang membuatnya harus kerap bepergian ke berbagai kota di dalam dan luar negeri yang masuk dalam kode semik.

(46) “Ajengan pasti sangat lelah,” desis Mang Embot yang terkejut mengetahui suhu tubuh Haji Dulgani lebih tinggi dari biasanya. *Leksia ini masuk dalam kode hermeneutika karena menggambarkan adanya tema berupa penyakit yang dialami oleh tokoh Haji Dulgani. **Leksia ini juga masuk dalam kategori penundaan jawaban kode hermeneutika ketika gangguan kesehatan menjadi inti dari masalah sang tokoh Haji Dulgani. Dalam leksia ini yang terkait pula dengan leksia 47, 49, dan 50, pembaca seolah diajak untuk menduga apa masalah kesehatan yang dialami Haji Dulgani. *** Gangguan kesehatan yang dialami tokoh Haji Dulgani mulai mendapatkan jawaban lewat gejala yang dialaminya.

(47) Hampir dua jam kemudian, Haji Dulgani terbangun dan bersin beberapa kali. Leksia ini masih masuk dalam kategori jawaban sebagian dalam kode hermeneutika karena terkait dengan leksia 46 yang juga mendeskripsikan masalah kesehatan yang dialami Haji Dulgani sehingga pembaca mulai bisa menebak penyakit yang diderita sang tokoh.

(48) “Maafkan saya," katanya berdiri dan mengambil sesuatu dari dalam tas. Amplop tebal dan kumpulan benang safron dalam plastik tembus pandang. "Safron Mang Embot pasti sudah habis ya?" "Betul, Ajengan,” jawabnya lirih agar tidak terkesan sedang meminta. "Alhamdulillah. Berarti cocok. Ini ambil lagi." “Cocok, Ajengan. Terima kasih." Leksia ini masuk dalam kategori kode aksi terkait dengan tindakan pengobatan yang dilakukan dengan menggunakan safron. **Leksia ini juga dikaitkan dengan kode simbolik lewat keberadaan amplop yang merupakan simbol dari pemberian uang.

(49) Mang Embot teringat pesan istri Haji Dulgani. “Badan Ajengan agak panas. Apakah tidak sebaiknya ke dokter?” Pada leksia 49 dan 60, hadir upaya 
pengobatan untuk menyembuhkan sakit sang tokoh. Upaya ini masuk dalam kode aksi naratif lantaran ada upaya untuk mengobati penyakit yang ada.

(50) “Ah, tidak perlu. Kalau sudah dipegang Mang Embot, sebentar lagi juga sembuh." Haji Dulgani mengibaskan tangannya. "Saya hanya perlu tidur sebentar lagi." Dalam leksia ini, pembaca seolah diajak untuk menduga apa masalah kesehatan yang dialami Haji Dulgani sehingga masuk dalam kode tekateki dengan kategori penundaan jawaban.

(51) Safron pemberian Haji Dulgani diberikan Mang Embot kepada istrinya yang lalu membuatkan minuman. Hari itu Mang Embot merasakan tubuhnya segar kembali, sehingga dia menghabiskan waktu dengan membersihkan sudut-sudut masjid tanpa merasa lelah. Para pengurus dan jamaah terkagum-kagum padanya. Leksia ini masuk dalam kategori kode aksi terkait dengan tindakan pengobatan yang dilakukan dengan menggunakan safron.

(52) Keesokan harinya Mang Embot kesulitan bangun pada jam tiga dini hari seperti biasa. Persendian tubuhnya ngilu, beberapa kali dia terbatuk.

(53) Istrinya menjerang air panas. Namun setelah melihat Mang Embot masih terbaring lunglai, dia menyarankan agar sang suami shalat Subuh di rumah saja. Mang Embot bangkit dengan susah payah. "Aku belum pernah ketinggalan shalat Subuh selama 40 tahun menjadi merbot.” Leksia 52 dan 53 turut memicu teka-teki dan kekacauan sehingga masuk dalam kode hermeneutika.

(54) Selama Subuh berjamaah Mang Embot menahan bersin yang menderu-deru di rongga dada, sehingga begitu mengucapkan salam dia menghambur ke kamar mandi, melampiaskan bersin berkali-kali. Ulu hatinya seperti teronggok bara api. Leksia ini menunjukkan adanya sebagian jawaban dari masalah kesehatan yang dialami tokoh tersebut sehingga masuk dalam kode hermeneutika.

(55) Biasanya usai Subuh Mang Embot tak pernah tidur sebelum membaca Alquran satu juz sampai tiba waktu syuruq. Kali ini badannya tak mau diperintah otaknya. Badannya membangkang ingin istirahat, membuatnya tertidur sampai Zuhur. Saat terbangun alih-alih badan segar, justru tenggorokan kering dan demam samar. Gejala penyakit yang muncul akibat dari penyebaran 
virus dihadirkan lewat sejumlah leksia di antaranya leksia 45, 46, 47, 52, 53, 54, 55, 61, dan 62. Dalam leksia-leksia tersebut, kita memperoleh pengetahuan tentang penyakit tanpa nama tersebut lewat gejala-gejala yang dialami oleh penderitanya sehingga bisa masuk dalam kategori kode kultural atau referensial.

(56) Istrinya melarang ke masjid. "Nanti malah menulari jamaah. Mau begitu? Zalim namanya," katanya kesal. * Leksia ini masuk dalam kode aksi serta menunjukkan adanya sikap toleransi dan empati terhadap jamaah lain agar tidak sampai tertular penyakit sehingga tepat masuk dalam kategori kode kultural.

(57) Yang tidak diketahui Mang Embot dan istri, pada saat yang sama Haji Dulgani dipaksa keluarganya ke rumah sakit di kota, langsung rawat inap. *Leksia ini turut memicu masalah sehingga masuk dalam kode hermeneutika dengan kategori teka-teki dengan jawaban sepenuhnya.

(58) Bahkan diisolasi terpisah karena pemeriksaan medis menunjukkan pedagang itu terjangkit infeksi dari luar negeri. (59) Satu demi satu pasien lain juga berdatangan, menunjukkan gejala serupa dengan Haji Dulgani. *Kedua leksia ini termasuk dalam kategori kode hermeneutika yang menggambarkan adanya penyakit yang berasal dari luar Tanah Air. Ini termasuk dalam tema yang mengarah pada adanya penyebaran penyakit yang masif. **Kondisi Haji Dulgani yang menjalani perawatan juga menimbulkan kekacauan sehingga masuk dalam kategori jawaban sepenuhnya kode hermeneutika.

(60) Keesokan harinya kesehatan Mang Embot kian anjlok. Sang istri meminta bantuan tetangga untuk membawanya ke Puskesmas, yang merujuk merbot sepuh itu ke RS yang sama dengan Haji Dulgani. Leksia ini sebangun dengan leksia 49 yang menggambarkan tindakan pengobatan yang masuk dalam kode aksi.

(61) Di perjalanan, Mang Embot merasakan paru-parunya sakit sekali. Kondisi kesehatan Mang Embot disebut makin memburuk karena mengalami gangguan kesehatan pada organ paru-parunya yang sakit. Leksia ini pun menimbulkan kekacauan dan masuk dalam kode hermeneutika karena penyakit ini tiba-tiba terkait dengan gangguan pada organ paru-paru si tokoh. 
(62) Napasnya semakin payah, tersendat-tercekat. Leksia 61 dan 62 memberikan jawaban lebih jelas tentang kondisi penyakit yang dialami Mang Embot. Pembaca pun tampaknya sudah mulai menebak penyakit yang diderita Mang Embot sehingga masuk dalam kategori jawaban sebagian kode hermeneutika.

(63) Matanya yang mengabur melihat segelas air minum rendaman putik bunga safron disodorkan kepadanya, namun bukan tangan istrinya. Tangan itu susah digambarkan karena belum pernah dia lihat seumur hidup. Terlihat juga kibasan sayap dari makhluk yang juga tak bisa dijelaskannya.

*Leksia ini masuk dalam kode hermeneutika kategori kekacauan yang timbul lantaran adanya makhluk yang mengibaskan sayapnya tanpa diketahui wujud sesungguhnya. **Leksia 64 dan 65 pun menggambarkan situasi sang tokoh ketika disebutkan bertemu dengan makhluk yang diduganya sebagai malaikat maut yang tepat masuk dalam kode semik atau konotatif.

(64) “Apakah engkau malaikat Izrail yang ditugaskan Allah untuk menjemputku?" Mang Embot berjuang keras melontarkan tanya. Makhluk itu mengangguk. *Sosok Izrail yang telah disebutkan dalam judul dan pada teks akhirnya terungkap dengan jelas pada leksia ini sehingga masuk dalam kategori jawaban sepenuhnya dalam kode hermeneutika. **Leksia ini juga menegaskan keberadaan makhluk bersayap yang sempat membingungkan sang tokoh utama yang sempat disimbolkan dengan sayap.

(65) Pertanyaan Mang Embot tak terdengar oleh istrinya. Yang dilihat perempuan itu hanya senyum sang suami mengembang perlahan berbarengan ucapan lirih yang meluncur lancar, "Asyhadu an laa ilaaha illallah. Wa asyhadu anna Muhammadan rasulullah.” Leksia ini memberikan sebagian jawaban dari teka-teki kondisi terakhir yang dialami Mang Embot. Leksia 65 dan 66 menggambarkan kebahagiaan yang dialami oleh tokoh Mang Embot saat mengembuskan napas terakhir yaitu lewat senyuman, ucapan kalimat syahadat, serta matanya yang menutup dengan sempurna yang masuk dalam kode semik.

(66) Setelah itu mata Mang Embot menutup sempurna. Leksia ini menjawab sebagian dari kondisi Mang Embot meski belum sepenuhnya 
meyakinkan sehingga dimasukkan dalam kode hermeneutika. Selain itu, leksia ini menghadirkan simbol kematian yang dipaparkan lewat mata yang telah menutup sempurna.

(67) Istrinya kini paham apa yang terjadi. Ditahannya derai tangis yang siap memburai. Dari bibir tuanya yang kisut, perempuan salehah itu bergumam sedih, "Innalillahi wa inna ilaihi raji'un. Allahummaghfirlahu warhamhu wa'afihi wa'fu'anhu." Nasib Mang Embot yang berujung pada kematian masuk dalam kategori jawaban sepenuhnya kode hermeneutika. Leksia 65, 66, dan 67 pun menyatakan kepergiaan tokoh Mang Embot lewat kalimat dan bacaan yang dilafazkan sehingga masuk dalam kode kultural atau referensial.

\section{Simpulan}

Penelitian terhadap cerpen 'Putik Safron di Sayap Izrail' karya Akmal Nasery Basral yang terbit di Harian Republika pada tanggal 17 Mei 2020 memiliki 67 leksia. Leksia-leksia tersebut pun dijabarkan dalam lima kode dari semiotika Barthes. Dari kode-kode yang diperoleh, selanjutnya dilakukan identifikasi dan ditafsirkan ke dalam makna-makna tertentu baik makna yang dapat dilihat secara implisit maupun eksplisit. Dari pemaknaan tersebut diperoleh kesimpulan bahwa cerpen ini mengangkat isu kesehatan berupa penyakit menular yang saat ini melanda seluruh dunia. Hal ini terungkap lewat leksia-leksia yang mengungkapkan aktivitas tokoh utama bepergian ke sejumlah negara. Selain itu, hadir pula penggambaran tentang kedaruratan penyakit tersebut yang menimbulkan kecemasan sosial. Dalam teks tersebut, pembaca pun diajak untuk memahami kegawatan yang terjadi sekaligus menebak penyakit yang menyebar luas itu lewat gejala-gejala yang dialami oleh tokoh-tokoh dalam teks. Ujung dari kegawatan itu, gambaran alam baka pun hadir yang menyimbolkan adanya kematian.

\section{Daftar Pustaka}

Astika, I. M. (2014). CERPEN “KISAH PILOT BEJO” KARYA BUDI DARMA (ANALISIS SEMIOTIKA ROLAND BARTHES). Prasi: Jurnal Bahasa, Seni, Dan Pengajarannya, 9(18), 15. 
Lantowa, J., Marahayu, N. M., \& Khairussibyan, M. (2017). Semiotika: Teori, Metode, dan Penerapannya dalam Penelitian Sastra. Deepublish.

KPCPEN. (2020). PROTOKOL PERCEPATAN PENANGANAN PANDEMI COVID-19 (Corona Virus Disease 2019).

Tarsinih, E. (2018). KAJIAN TERHADAP NILAI-NILAI SOSIAL DALAM KUMPULAN CERPEN "RUMAH MALAM DI MATA IBU" KARYA ALEX R. NAINGGOLAN SEBAGAI ALTERNATIF BAHAN AJAR. Bahtera Indonesia, 3.

Tatag, A. D. (2014). ANALISIS STRUKTURALISME DALAM CERITA PENDEK "DIE POSTKARTE" KARYA HEINRICH BÖLL. UNIVERSITAS NEGERI YOGYAKARTA.

Siswanto, W. (2008). Pengantar Teori Sastra. Grasindo.

Widyatwati, K. (2015). CERPEN FARUK “BUS KOTA” DALAM SEMIOTIK ROLAND BARTHES. Humanika, 22. 